\title{
The First Domestication: How Wolves and Humans Coevolved. By Raymond Pierotti and Brandy R. Fogg. 2017. Yale University Press, New Haven. 326 pp.
}

\author{
Eugene N. Anderson ${ }^{1 *}$ \\ ${ }^{1}$ Department of Anthropology, University of California, Riverside, USA. \\ gene@ucr.edu
}

Received August 15, 2018

OPEN ठ ACCESS

Accepted August 16, 2018

DOI 10.14237/ebl.9.2.2018.1379

Copyright (c) 2018 by the author(s) licensee Society of Ethnobiology. This is an open-access article distributed under the terms of the Creative Commons Attribution-NonCommercial 4.0 International Public License (https://creativecommons.org/licenses/by-nc/4.0), which permits non-commercial use, distribution, and reproduction in any medium, provided the original author and source are credited.

Human-wolf coevolution involves several components. First is the initial bond between humans and wolves. This was formed, presumably, when humans got into wolf country and slowly learned to co-hunt with them. Second is the development of the domestic dog. Third is living with wolves and dogs today, including keeping wolves as household companions. The initial bond was probably formed as humans got into the game-rich steppes and forests inhabited by large gray wolves (Canis lupus). This would have been after modern humans left Africa. Pierotti has long argued, and Fogg has found further evidence, that humans did not domesticate dogs as scavengers or pets, but started out by working more and more closely with wolves as hunters, and finally began to domesticate them-or perhaps the wolves domesticated themselves, evolving more and more fondness for working with humans. Wolves and ravens routinely co-hunt; there are probably other such partnerships. The extreme sociability of wolves is based on their close teamwork as pack hunters, conceivably easily transferable to other species when occasion arises.

This theory fits with the increasing evidence for multiple domestication events in the history of the dog. Recent claims for the origin of the dog in China, central Asia, western Eurasia, and the Near East have all been made. Pierotti and Fogg see no reason for any of these to be wrong. If people were working with wolves and the transition was gradual, one would expect multiple crossings and back-crossings, plenty of gene flow from each site to others, and a gradual and uneven tradition. The authors believe that
Native American Plains dogs may have been simply tamed wolves.

Domestication led to neoteny, tameness, and obedience, but broke the tight family life of the wolf. Modern dogs are bred to follow our orders-unlike wolves, they learn easily to follow pointing fingersbut live in amorphous groups, without the firm dominance of an alpha male and alpha female that one sees in wolf packs. Domestication has led more recently to elaboration of countless breeds of dogs, with different personalities and abilities. Backcrossing to wolves has been important in some breeds, such as the German shepherd.

Dogs continue to be loved as companions, even among Muslims, who deem dogs unclean. A delightful medieval Arab work has been translated as The Book of the Superiority of Dogs to Many of Those Who Wear Clothes (Ibn al-Marzubān 1978); the Arabic title is a bit of "doggerel" itself, and could be translated "Dogs Beat Togs."

Pierotti has longterm experience with both wild and tame wolves, with wolf-dog crosses, and with various kinds of dogs. He writes as a highly sensitive expert on how to manage various canines. Wolves require firm but sensitive handling and they can be as tame as dogs, a point confirmed by the many wolfsaving organizations I follow.

A major theme of this book is the widespread understanding of wolves, and even affection for them, by Indigenous peoples, contrasted with the modern European and Euro-American fear and hate of wolves. Pierotti and Fogg know best the North 
American Native views, which they compare with the Australian Aboriginal affection for dingoes (they cite Deborah Rose's superb publications on this, among others; see Rose 2000). They also cover Siberia and Central Asia, where the Turks claim descent from wolves and the Mongols from the marriage of a gray wolf to a fallow doe-courage and loyalty united with beauty and grace. There is even an eyewitness account of a tamed wolf suckling a human toddler in a Canadian First Nations household.

There is comparative European data; one instantly thinks of Romulus and Remus. On the Capitoline Hill in Rome stands a powerful, evocative, and artistically brilliant statue: a life-sized bronze shewolf, looking directly at the viewer, with an expression of tenderness, protection, and courage. She is suckling the twins. She is just abstracted enough to convey the pure visionary essence of wolf; the artist saw through the surface and caught the soul. $\mathrm{He}$, or she, lived far enough back in history to take such spiritual artistry quite seriously. The current wolf dates from about AD 1100 (Wikipedia, "Capitoline Wolf") but is probably a copy or re-creation of an Etruscan or Roman sculpture from much earlier times. Treatment of wolves in the early Celtic epics, also, is very much like that documented by Pierotti and Fogg for Native Americans.

How did wolves become the embodiment of evil found in Grimms' fairy tales and other folk sources? Pierotti and Fogg document Christian anti-wolf writings and indeed the wolf is not treated very well in the Bible. Settled farm life that was heavily dependent on small stock is clearly responsible for much antiwolf sentiment. Also involved is hate and fear of wild nature, a hate traceable to the irrigated plantations of Mesopotamia. Wolves became scary as lions disappeared, exterminated from Europe by the Romans and others. Europe became more and more wolf-averse, climaxing in the hate and fear of wolves that we have recently seen in rural America as wolves and coyotes become more widespread.

Pierotti and Fogg document at some length the incompetence of many writers on dogs and wolves. They are especially critical of Coppinger and Coppinger (2001). The Coppingers retain old European attitudes: animals are basically automatons, as argued by Descartes (1999, Latin original 1637; see pp. 40-41). Dogs and wolves are totally distinct animals to the Coppingers, which flies in the face of science and common experience. The Coppingers also argue that dogs were domesticated from wolves that were scavengers around human camps. Humans adopted "cute" pups and slowly selected for tameness. Pierotti has long argued against this view, showing many reasons why it would not have worked. The cohunting hypothesis fits better what we know of people and early dogs.

One can add to this. Ádám Miklósi, a Hungarian dog researcher, has recently maintained the same Cartesian point (Miklósi 2018). It seems incredible that in the twenty-first century anyone could maintain that any higher animal is a machine, lacking true emotions and motivated by food; Miklósi holds this and even claims dogs do not love, they merely are conditioned to expect food from their owner. (This does not explain why some dogs care little about food rewards but crave and can be trained by cuddling, walks, and petting.)

Anyone that has lived with multiple dogs knows that they have different personalities and knowledge bases. They take advantage of each other all the time, using knowledge of each other's lapses in awareness. They also use their knowledge to help or support or protect or fight or trick a pack-mate who has a different personality and knowledge pool. They are also exquisitely attuned to differences between humans and know how to "work" their owners for food, walks, and petting, adjusting their appeal to personality differences. This requires a highly developed "theory of mind."

Pierotti and Fogg describe differences between wolf and dog communicative behavior, but do not go into details. Dogs communicate by scent more than by other channels; second, in any even slightly complex transaction, they use whole-body visual cues, diverse vocal sounds, and a whole bank of pheromones to communicate-integrating all these into a single message.

Most dog books barely mention scent. There is now, finally, a book devoted to it: Secrets of the Snout by the Norwegian dog trainer Frank Rosell (2018). Even this book is more concerned with training than with natural communication, but it does have full details on dog noses and olfactory senses. Dogs have about a million times the scenting ability of humans. We miss $99.9999 \%$ of what is going on in their scent-world. We can smell the pleasure/play pheromone, which is pleasant and reassuring to humans as to dogs, and the extreme fear scent, smelling like rotten onions.

Dogs have many scent glands, each secreting a 
whole suite of different chemicals and each dog has his or her own special mix of these, allowing individual recognition. Dogs have been tested with mirrors to see if they have a knowledge of self, but this is foolish; dogs recognize self and others primarily by scent, not sight, as several authorities have pointed out. I have often confronted puppies with their first mirrors. The pup sniffs at the strange dog, finds it has no smell, and dismisses it as a mere trick of the light.

We all know that dogs (and also coyotes and wolves) howl along with sirens, but less well known is their musical ability. My cattle dog, when young, would accompany records on his squeaky-toys and matched the records perfectly in pitch and timing. The climax was a long duet with Andres Segovia, the Master playing his guitar, the dog accompanying him perfectly on the squeaky-toy. Segovia must have rolled in his grave. As to wolves: I once camped in a remote part of British Columbia and soon found that the next site was occupied by a saxophonistobviously a professional, from his playing. He and the neighboring wolf pack traded riffs half the night. The wolves would howl, my neighbor would copy their songs on his sax. The wolves would then howl something new but with the same timing and pitch. It went for hours. I suspect my neighbor had seen the film "Never Cry Wolf," in which the hero duets with wolves on his bassoon. In any case, the whole performance was quite amazing.

Dogs combine visual, auditory, and olfactory channels in productive ways. These combined messages are very poorly understood, even by experts. Dogs also fail to make the complex plans for the far future that humans make, but dogs are surprisingly good at short-term planning. Since wolves have $1 / 3$ more brain than dogs, they are probably more intelligent.

Pierotti and Fogg say a good deal about coyotes, but nothing strikingly new. They deal with Coyote's
Perspectives from Gene Anderson's bookshelf

trickster role in song and story, so comparable to Old World fox lore. They note that coyotes, unlike wolves, do not tame, and that this may be related to their living in pairs rather than packs. Coyote young disperse within a year, though they may revisit or join periodically for hunting. I have seen some joyful and moving reunions when a pup comes home to visittail-wagging, rolling over, play-fights, and other doglike behaviors occur.

Of all the many books about wolves and dogs that I have read, this is the best. It is a "must read" for ethnozoologists, and surely for dog owners and lovers.

\section{References Cited}

Coté, C. 2010. Spirits of Our Whaling Ancestors: Revitalizing Makah and Nuu-chah-nulth Traditions. University of Washington Press, Seattle, WA.

Coppinger, R., and L. Coppinger. 2001. Dogs: $A$ Startling New Understanding of Canine Origin, Behavior and Evolution. University of Chicago Press, Chicago.

Descartes, R. 1999 [1637]. Discourse on Method and Related Writings. Penguin, New York.

Miklósi, Á. 2018. The Dog: A Natural History. Princeton University Press, Princeton, NJ.

Ibn al-Marzubān, M. I. K. 1978. The Book of the Superiority of Dogs over Many of Those Who Wear Clothes, edited and translated by G. R. Smith and M. A. S. Abdel Haleem. Aris and Phillips, Warminster, United Kingdom.

Rose, D. 2000. Dingo Makes Us Human: Life and Land in an Australian Aboriginal Culture. Cambridge University Press, New York.

Rosell, F. 2018. Secrets of the Snout: The Dog's Incredible Nose. University of Chicago Press, Chicago. 